\title{
HARMONI DALAM KEBHINEKAAN \\ (Kearifan Lokal Masyarakat Pulau Enggano Provinsi Bengkulu Dalam Mengatasi Konflik)
}

\author{
Intan Permata Sari ${ }^{1}$
}

\begin{abstract}
Ethnic and religious conflicts are still a hot conversation in early 2017. Discourses on non-Muslim Muslims as well as indigenous non-indigenous peoples are the main topics in various news in Indonesia. Peace that has been maintained, post-conflict that occurred in Sampit and Ambon, suddenly disturbed. People in Indonesia are again divided into religious groups (Muslim or non-Muslim) or ethnic groups (indigenous or non-indigenous). However, Indonesia has the hope to make peace in the differences and make it harmony in society. We can learn from Enggano society. The people of Enggano are the people who live in one of the outer islands in Indonesia. The island is located in the west of Sumatra Island. The Enggano people are able to live in diversity even though their lives are far from prosperous, poor access and facilities, and far from the government's attention. Almost no conflict occurred on this island. This is because Enggano local wisdom is so strong that it can bridge the differences.
\end{abstract}

Keywords: Enggano society, conflict, harmony, local wisdom, Bengkulu, ethnicity, religion

\begin{abstract}
Abstrak
Konflik etnis dan agama masih menjadi perbincangan hangat di awal tahun 2017. Wacana mengenai muslim non muslim serta pribumi non pribumi, menjadi topik utama dalam berbagai berita di Indonesia. Kedamaian yang selama ini dijaga, pasca konflik yang terjadi di Sampit dan Ambon, tiba-tiba terusik. Orang-orang di Indonesia kembali terkotak-kotak menjadi kelompok-kelompok agama (muslim atau non muslim) atau kelompok-kelompok etnis (pribumi atau non pribumi). Akan tetapi, Indonesia memiliki harapan untuk berdamai dalam perbedaan-perbedaan dan menjadikannya harmoni dalam masyarakat. Kita bisa belajar dari masyarakat Enggano. Masyarakat Enggano merupakan masyarakat yang tinggal di salah satu Pulau terluar di Indonesia. Pulau ini terletak di sebelah barat Pulau Sumatra. Masyarakat Enggano mampu hidup dalam kebhinekaan meskipun kehidupan mereka jauh dari kata sejahtera, akses serta fasilitas yang masih buruk, dan jauh dari perhatian pemerintah. Hampir tidak ada konflik yang terjadi di Pulau ini. Hal ini dikarenakan kearifan lokal Enggano yang begitu kuat sehingga mampu menjembatani perbedaan-perbedaan tersebut.
\end{abstract}

Kata-kata Kunci: masyarakat Enggano, konflik, harmoni, kearifan lokal, Bengkulu, etnisitas, agama

\footnotetext{
${ }^{1}$ Institut Agama Islam Negeri Bengkulu, Email: intanpermatasari1112@gmail.com 


\section{A. PENDAHULUAN}

A khir-akhir ini, stabilitas negara kita sedang terganggu. Konsep Bhineka Tunggal lka yang selalu menjadi pedoman dalam berbangsa dan bernegara sedang dipertaruhkan eksistensinya. Masyarakat Indonesia sedang diuji dengan isu Suku, Agama, Ras, dan Antar Golongan (SARA). Orang-orang Islam tiba-tiba bersatu dan menyuarakan kehendaknya melalui aksi bela Islam yang berjilid-jilid, begitu juga dengan kaum minoritas yang menganggap bahwa Indonesia bukan hanya milik masyarakat yang beragama Islam. Tiba-tiba saja identitas primordial menguat. Mulai ada bahasan mengenai pribumi dan bukan pribumi atau masyarakat Indonesia yang asli dan tidak asli.

Isu SARA memang menjadi hal yang sangat sensitif bagi mayoritas orang Indonesia. Hal-hal yang menyangkut agama dengan cepat menjadi bahasan hangat terutama menjelang pemilihan Kepala Pemerintahan. Masih hangat di ingatan kita ketika Pemilihan Presiden tahun 2014, isu SARA sangat kuat dan merugikan salah satu calon presiden. Jokowi digalang-galang sebagai Cina, antek-antek Cina, PKI, dan Kristen (Sari, 2015). Tentu saja isu tersebut memberikan pengaruh kepada jumlah pemilih Jokowi. Begitu juga yang terjadi pada kasus Ahok. Ahok jelas-jelas warga Indonesia yang beretnis Tionghoa dan beragama Kristen. Sangat mudah untuk menjatuhkan Ahok karena memang masyarakat Indonesia sangat sensitif dengan sesuatu yang menyangkut SARA.

Faktanya, Indonesia terdiri dari ratusan etnis dan enam agama yang diakui oleh pemerintah. Indonesia bukan hanya milik orang-orang yang beragama mayoritas pun bukan hanya milik etnis mayoritas. Dari awal, para pendiri bangsa sudah menduga bahwa keanekaragamaan suku, budaya, dan agama akan menjadi masalah di kemudian hari. Terbukti dari lepasnya TimorTimor pada tahun 1999. Begitu pula yang dilakukan Papua, Maluku, dan Aceh dengan percobaan melepaskan diri menjadi Negara Kesatuan Republik Indonesia (NKRI). Ambon bergejolak. Sampit pun penuh dengan darah. Konflik-konflik terus terjadi. Masalah tidak pernah jauh dari unsur SARA. Selalu mengenai konflik etnis dan agama.
Konflik terjadi karena ada kesenja ngan sosial ekonomi dan perlakuan deskriminatif terhadap class forming yang dipaksakan sehingga menyebabkan kelompok tertentu merasa diperas dan dipinggirkan (Pelly, 1999). Pelly juga mengatakan bahwa dengan kemasan etnis, kesetiawakawan (solidaritas) mudah dibangkitkan dan dengan kemasan agama, pengesahan (legitimasi) serta landasan sakral akan mudah pula di dapatkan.

Stanfield II (dalam Abdullah, 2001) mengatakan bahwa etnis tidaklah hadir dalam suatu ruang kosong, tetapi hadir dalam suatu parameter sosial. Etnis melekat pada kelas, gender, usia, wilayah, dan agama atau pada sumberdaya (ekonomi) yang tersedia. Abdullah (2001) juga mengatakan bahwa pola hubungan antaretnis itu ditentukan oleh tiga corak ruang yang menentukan karakter dari hubungan antaretnis itu sendiri. Pertama, berbagai etnis di Indonesia tersebar dalam wilayah-wilayahnya sendiri dengan batasbatas fisik (physical boundary) yang jelas menyebabkan pendefinisian diri lebih terikat pada daerah asal dan memiliki klaim terhadap asal usulnya sebagai pewaris tradisi dan wilayah. Kedua, berbagai etnis di Indonesia tersebar di berbagai tempat dengan batas-batas fisik yang semakin tidak jelas dan memiliki sejarah masa lalu yang berbeda dengan etnis-etnis yang terlibat dalam interaksi sosial sehari-hari. Ketiga, munculnya wilayah baru (seperti suburb) yang dibuka di berbagai tempat yang menyebabkan terjadinya pertemuan antaretnis dalam suatu wilayah yang telah mengalami redefinisi atas status tanah dan wilayah yang bebas dari pemilikan suatu etnis.

Akan tetapi, faktor-faktor yang menyebabkan konflik etnis yang selama ini ditulis oleh para ahli tidak berlaku pada masyarakat Pulau Enggano. Pulau ini terletak di bagian barat Pulau Sumatra, Provinsi Bengkulu. Pulau kecil yang hanya beranggotakan kurang lebih 4000 orang yang berasal dari berbagai suku bangsa dan juga berbagai macam keyakinan. Enggano bisa menjadi contoh bagaimana keraga maan mampu hidup tanpa adanya konflik. Keterbatasan akses, fasilitas, dan perhatian pemerintah tidak membuat masyarakat Enggano mencari perhatian lebih dengan 
melakukan tindakan anarki dan konflik. Mereka bahkan jauh dari kata konflik, hampir tidak ada konflik di dalam masyarat. Ini dikarenakan kearifan lokal yang terus dilaksanakan serta aturan-aturan adat yang kuat. Tulisan ini akan memberikan gambaran bagaimana sekelompok masya rakat kecil, terpinggirkan secara ekonomi, sosial, politis, dan geografis mampu melihat perbedaan etnis dan agama secara lebih bijak sehingga tercipta harmoni di dalam masyarakat.

\section{B. TINJAUAN PUSTAKA}

nformasi mengenai Pulau Enggano tidak mudah untuk ditemukan. Akan tetapi Nursyirwan Effendi (dalam Koentjara ningrat, 1993) sudah pernah menuliskannya dalam buku Masyarakat Terasing di Indonesia. Tulisan ini berisi informasi umum mengenai Enggano. Dalam tulisan ini diceritakan mengenai asal-usul nama Enggano, lokasi Pulau Enggano, demografi, mata pencarian, organisasi sosial, religi, dan kesenian.

Tulisan yang lebih menarik sebenar nya ditulis oleh Ekorusyono. Meskipun beliau bukanlah seorang antropolog, tetapi tulisannya yang berjudul "Mengenal Budaya Enggano" ditulis cukup rapi, penuh informasi, dan ditulis seperti menulis sebuah etnografi. Tulisan ini mampu menggam barkan budaya masyarakat Enggano, asalusul, sistem kekerabatan, religi, dan lain sebagainya.

Penelitian tentang Enggano juga tidak banyak dilakukan terutama yang berkaitan dengan konflik. Hanya penelitian yang dilakukan oleh Dr. Zulkarnaen, S.,M.Ag, dkk pada tahun 2002 mengenai Model Interaksi Sosial antar Umat Beragama di Enggano. Tulisan ini mengatakan bahwa tidak ada konflik yang terjadi antar umat beragama di Enggano dikarenakan ada sistem dalam kearifan lokal yang mengatur tingkah laku manusia di Enggano agar sesuai dengan aturan adat yang berlaku.

Penelitian lain juga pernah dilakukan tetapi berkaitan dengan 1) transmigrasi yang dilakukan oleh Harmiati, $\mathrm{dkk}^{2}$; 2) penelitian tentang Kajian Ketahanan Pangan Masyarakat Enggano dan Efeknya terhadap
Kesejahteraan, yang dilakukan oleh Indra Cahyadinata, dkk $(2009)^{3}$; 3) penelitian terkait dengan bahasa (Yoder, 2006). Sisanya, penelitian mengenai Enggano dilakukan oleh peneliti-peneliti Belanda, seperti Keuning (1955), M.A.Jaspan (1964), dan Keurs (2002). Akan tetapi, penelitipeneliti dari Belanda banyak menggunakan bahasa Belanda sehingga sulit untuk dipahami.

\section{MENGENAL ENGGANO}

K ata Enggano berasal dari kata Portugis yang berarti "kecewa". Nama ini muncul sekitar abad ke-17 orang Portugis singgah ke Pulau ini mencari rempah-rempah yang ternyata tidak ditemukan. Semenjak itu Pulau ini dikenal dengan nama Enggano. Di masa penjajahan Belanda, Pulau Enggano disebut Pulau Telanjang karena ketika itu kehidupan masyarakat Enggano masih sederhana dan belum mengenal tekstil (Effendi, $1993: 74$ ).

Pulau Enggano merupakan salah satu dari 92 pulau kecil terluar di Indonesia. Di Sumatra hanya ada tiga pulau kecil, dua diantaranya merupakan pulau kecil terluar, yaitu Pulau Enggano dan Pulau Mega (Peraturan Presiden RI Nomor 78 Tahun 2005) sedangkan sisanya adalah Pulau Tikus, yang terletak di Bengkulu tetapi tidak termasuk katagori pulau terluar. Enggano adalah satu-satunya pulau kecil terluar yang berpenghuni di Propinsi Bengkulu. Pulau Enggano terletak di sebelah barat pulau Sumatra yang berjarak kira-kira $156 \mathrm{~km}$ dari Pelabuhan Pulau Bai, Provinsi Bengkulu. Pulau Enggano memiliki panjang pulau berukuran $40 \mathrm{~km} \times 17 \mathrm{~km}$. Pulau Enggano terdiri dari enam desa, yaitu Desa Kahyapu, Desa Kaana, Desa Malakoni, Desa Apoho, Desa Meok, dan Desa Banjarsari.

Jarak antar desa di Pulau enggano cukup jauh. Butuh waktu kurang lebih 2,5 jam untuk bisa menempuh ujung pulau ini. Desa Kahyapu adalah desa pertama dari pelabuhan Kahyapu. Jarak dari pelabuhan ke Desa kedua, yaitu Desa Kaana adalah 7 $\mathrm{km}$. Desa Kaana ke desa Malakoni berjarak $10 \mathrm{~km}$. Desa Malakoni ke Desa Apoho berjarak $1 \mathrm{~km}$. Desa Apoho merupakan pusat kecamatan Enggano, ada banyak

${ }^{2}$ Universitas Hazairin

${ }^{3}$ Penelitian dibiayai oleh DIPA Unib tahun 2009 
fasilitas pemerintah di desa ini. Jarak dari Desa Apoho ke Meok sejauh $3 \mathrm{~km}$. Jarak dari Desa Meok ke Banjarsari, yang merupakan ujung Pulau Enggano, sejauh 17 $\mathrm{km}$.

Pulau Enggano bisa ditempuh dengan menggunakan kapal penyeberangan (Kapal Feri Pulo Tello) dengan waktu tempuh 12 jam. Kapal Feri ini beroperasi seminggu dua kali dengan jadwal Selasa dan Jumat (Bengkulu-Enggano) serta Rabu dan Sabtu (Enggano-Bengkulu). Meskipun memiliki jadwal tetap, tetapi waktu keberangkatan yang sebenarnya ditentukan oleh keadaan cuaca, apakah cukup memadai untuk berlayar atau tidak. Jika kapal tidak bisa diberangkatkan sesuai jadwal, maka keberangkatan akan dijadwalkan keesokan harinya atau menunggu cuaca bersahabat.

Untuk dapat mengelilingi pulau Enggano, tidak ada alat transportasi darat yang tersedia sehingga alat transportasi harus dibawa sendiri dari Bengkulu. Untuk bisa menyebrang ke Enggano, kita harus membayar tiket kapal dengan harga $\mathrm{Rp}$ $57.000 /$ orang dan kendaraan bermotor $\mathrm{Rp}$ 112.000/ motor untuk sekali jalan. Jika membawa mobil, biaya yang harus dikeluarkan cukup besar, yaitu $R p$ 1.300.000/ mobil untuk sekali jalan. Biaya transportasi ini cukup mahal sehingga harga-harga di Enggano melambung sangat tinggi.

Di Enggano, akomodasi, transportasi, dan komunikasi cukup sulit. Hanya ada dua penginapan di Pulau ini. Hotel pertama terletak di dekat pelabuhan Kahyapu dan hotel 1 lagi terletak di Desa Malakoni. Tidak ada tempat makan apalagi restoran di Pulau Enggano, beberapa warung makan hanya buka ketika kapal mendarat. Tidak ada listrik. Listrik hanya ada di ibukota Kecamatan (Apoho) dan sekitarnya. Untuk mencukupi keperluan listrik, semua warga memiliki jenset, yang dihidupkan hanya pada malam hari. Akses komunikasi juga tidak lancar. Sinyal telepon hanya ada sekitar pukul 08.00-16.00 WIB, kecuali wilayah Apoho dan sekitarnya.

Kondisi jalan di Enggano juga cukup menyedihkan. Mayoritas jalan adalah tanah berbatu. Kondisi ini cukup menyulitkan ketika hujan turun karena akan sulit mengendarai kendaraan bermotor. Tidak ada transportasi lokal di Pulau ini. Setiap orang memang harus memiliki kendaraan bermotor sebagai media transportasi. Mobil tidak banyak. Hanya ada mobil dinas Kecamatan dan mobil angkutan hasil pertanian.

Penduduk asli Enggano terdiri dari lima suku, yaitu Kauno, Katora, Kaarubi, Kaharuba, dan Kahaoa. Akan tetapi, masyarakat asli Enggano mengakui suku pendatang dan memberikan mereka satu suku yang dinamakan suku Kaamay. Keenam suku ini hidup berdampingan dan hampir tidak ada konflik diantara mereka. Keenam suku ini memiliki kepala suku dan dibawahi oleh seorang kordinator suku yang dinamakan Pabuki. Pabuki memiliki kekuasaan setingkat Camat.

Suku pendatang (Kaamay) keba nyakan menetap di Desa Kahyapu, Desa Kaana, dan Desa Banjarsari. Ini dikarena kan wilayah ini masih cukup kosong dibandingkan dengan ketiga desa lainnya (Malakoni, Meok, dan Apoho). Ini dikarenakan pusat kecamatan terletak di Apoho dan sebelum adanya kapal Feri, kapal yang digunakan sebagai alat trasportasi adalah kapal perintis yang pelabuhananya terletak di Desa Malakoni.

Mayoritas masyarakat Enggano adalah petani. Kebanyakan dari mereka adalah transmigran yang memutuskan pindah dan menjadi warga Enggano dengan mengganti Kartu Tanda Penduduk (KTP) mereka. Alasan utama mereka memilih untuk menjadi warga Enggano karena di Enggano masih banyak lahan kosong yang diboleh diberikan kepada penduduk yang ingin pindah ke Enggano.

Tentu tidak diberikan begitu saja. Ada beberapa syarat yang harus ditempuh, misalnya adalah benar-benar ingin hidup di Enggano dengan mengganti KTP mereka menjadi KTP Enggano; hidup, menetap, dan bekerja di Enggano selama 6 bulan; berkelakuan baik; mendapat rekomendasi dari desa bahwa yang bersangkutan betulbetul ingin hidup di Enggano dan tidak ada indikasi untuk menjual tanah yang diberikan.

Hal tersebut tentu cukup berat. Terutama mereka harus tinggal dan bekerja di Enggano selama 6 bulan. Akan tetapi, impian untuk mendapatkan tanah gratis sebanyak 2 hektar, membuat mereka bersungguh-sungguh ingin menetap di Enggano. Biasanya, orang-orang ini adalah 
orang yang tidak memiliki pekerjaan, tanah, atau pun rumah di tempat tinggalnya dan memutuskan memulai hidup baru menjadi petani di Enggano.

Orang Enggano adalah masyarakat yang terbuka. Mereka dengan mudah bisa menerima pendatang ke wilayah mereka dan mereka tidak segan-segan untuk saling membantu. Wilayah Enggano yang tidak begitu besar dengan jumlah penduduk kirakira 4000 orang menyebabkan hampir semua dari mereka saling mengenal (kecuali para pendatang baru). Semua orang Enggano bisa berbicara bahasa Indonesia sehingga sangat mudah untuk para pendatang hidup dan bersosialisasi dengan penduduk asli.

Meskipun masyarakat Enggano cendrung terbuka, mereka menolak dengan tegas transmigrasi secara besar-besaran yang dilakukan pemerintah melalui Dinas Transmigrasi, meskipun ada beberapa desa yang sudah terlanjur memiliki ikatan kerjasama dengan Dinas Transmigrasi. Ini dikarenakan mereka betul-betul sadar bahwa potensi tanah yang mereka miliki tidak bisa diperbaharui sedangkan setiap saat ada saja orang-orang baru yang ingin masuk dan mendapatkan tanah di Enggano. Ini juga dikarenakan mereka mengantisipasi orang-orang yang baru menikah dan akan membentuk keluarga baru akan diberikan tanah oleh adat sebesar 2 hektar.

Terasingnya wilayah Enggano, tidak hanya dikarenakan kondisinya sebagai wilayah pulau terluar di Indonesia tetapi juga merupakan pulau terluar wilayah oleh Bengkulu. Secara politis, Provinsi Bengkulu tidak memiliki kekuatan untuk memaksa pemerintah pusat 'peduli' dengan kondisi masyarakat terluarnya. Dampaknya, kondisi kesejarahteraan masyarakat Enggano masih cukup memperhatinkan, transmigran sudah ada, mayoritas transmigran lokal dari Bengkulu, meskipun tidak begitu berdampak pada perekonomian masyarakat asli.

Di balik keterasingannya, Enggano bisa menjadi contoh bagi bangsa-bangsa lain di Indonesia. Orang-orang Enggano sangat memahami bahwa masalah tanah suatu saat akan menjadi potensi konflik yang luar biasa sehingga mereka memiliki kearifan lokal untuk membatasi jumlah pendatang. Mereka juga memiliki konsep tanah adat yang dijaga dengan ketat, tidak ada orang yang boleh memanfaatkan tanah tersebut selain dengan ijin adat. Mereka bahkan tidak memperbolehkan batang pohon yang ditebang dibawa keluar dari Pulau Enggano. Mereka lebih memilih batang pohon tersebut membusuk daripada dijual ke Bengkulu. Kayu-kayu pohon tersebut boleh dipergunakan untuk keperluan masyarakat Enggano dan boleh dibawa ke Bengkulu seperlunya dengan syarat sudah menjadi perabotan, misalnya meja, kursi, pintu tetapi dengan jumlah terbatas. Begitulah gambaran betapa ketatnya aturan adat dan tetap dipatuhi oleh semua masyarakat di Pulau Enggano.

\section{PERDEBATAN MENGENAI SEJARAH MASYARAKAT ENGGANO}

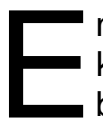

nggano memiliki sejarah yang cukup kompleks. Tidak ada yang benarbenar tahu siapa nenek moyang orang Enggano yang sebenarnya. Ada beberapa versi mengenai orang pertama yang menginjakkan kaki di Enggano. Para informan mengatakan bahwa pada zaman dahulu ada kapal yang terdampar di Enggano. Orang-orang di kapal ini pada akhirnya banyak yang meninggal dunia. Tersisalah satu laki-laki. Pada suatu hari dia memukul-mukulkan kayu ke karang dan tiba-tiba muncul lah wanita. Laki-laki tersebut dinamakan Kah Kamanippa dan perempuan dinamakan Nai Nippaha. Merekalah yang kemudian menjadi cikal bakal nenek moyang orang Enggano.

Legenda ini terus menerus dikonstruksi untuk menggambarkan bagai mana manusia pertama sampai ke Enggano. Akan tetapi, sejarah Enggano bisa dilihat dari penemuan mata uang Cina kuno yang berangka 421 Masehi yang bertuliskan Chien $\mathrm{Ma}$ (Ekorusyono, 2015 : 65). Penemuan ini sekaligus menegaskan bahwa Cina sudah masuk ke Enggano pada abad ke-5 M. Bangsa Portugis juga telah memasuki Enggano. Catatan penelitian Pulau Enggano, Pieters J. Ter Keurs dari Museum Nasional Ethnologi Belanda menyebutkan wilayah itu ditemukan pertama kali pada tahun 1.500 oleh awak kapal Portugis. Saat itu kapal Portugis singgah ke Pulau Enggano hendak mendapatkan air bersih dan perbekalan karena sudah bermingguminggu berlayar. Namun awak kapal 
Portugis mendapatkan kekecewaan di pulau itu karena sikap agresif penduduk yang menyerang dan mengusir mereka.

Enggano berasal dari Bahasa Portugis yang artinya "Kecewa" (Kompas, 18 Agustus 2016). ${ }^{4}$ Catatan yang dimiliki oleh Pabuki (koordinator adat setingkat Camat) menyatakan bahwa Portugis masuk ke Enggano untuk mencari hasil-hasil laut sambil memperdagangkan alat-alat tajam (tombak). Pada masa itu, Enggano sedang berperang antar suku (1500 M-1883 M) dan kedatangan Portugis memperjualbelikan senjata memperkuat persenjataan sukusuku yang ada di Enggano. Portugis pernah melakukan sensus penduduk di Enggano yang menyatakan bahwa jumlah penduduk Enggano pada masa itu sebanyak 10.000 orang. Jumlah itu jauh lebih besar dari penduduk Enggano sekarang yang kira-kira 4000 orang. Hal ini dapat dijelaskan melalui konflik yang berkepanjangan dan wabah penyakit (TBC, Malaria, dan kudis).

Jika dilihat dari sejarah, Enggano cukup menarik bagi bangsa lain. Hal ini kemungkinan disebabkan dengan jaraknya yang tidak begitu jauh dari Batavia. Enggano memiliki catatan sejarah pernah dikunjungi oleh bangsa Cina, Portugis, Inggris, Jerman, Belanda, dan Jepang. Kedatangan bangsa Cina dibuktikan dengan penemuan mata uang kuno; bangsa Portugis dari catatan-catatan sejarah; Inggris tidak bisa dilepaskan dari Bengkulu karena Inggris adalah negara yang menjajah Bengkulu sebelum Belanda; misonaris Jerman pernah datang ke Enggano pada tahun 1902 untuk menyebarkan agama Kristen Protestan dan membuka sekolah zending; Belanda pernah datang dan membuat catatan tentang Enggano; Jepang cukup lama menjajah Enggano setelah Belanda kalah tahun 1942-1945.

\section{E. HARMONI DALAM PERBEDAAN}

A khir-akhir ini banyak konflik yang terjadi di Indonesia. Belum lama ini, kasus Ahok menjadi kasus paling sensitif terkait dengan perbedaan agama dan suku bangsa. Tidak mudah melupakan

${ }^{4}$ http://regional.kompas.com/read/2016/08/18/2222 0051/Belajar.Keberagaman.dari.Suku.Petempur.di.Pul au.Enggano fakta bahwa Ahok telah menistakan agama Islam di Kepulauan Seribu tahun 2016 lalu. Melalui proses yang panjang, penuh dengan perdebatan, demo, aksi pendukung Islam yang berjilid-jilid, dan pada akhirnya menjadi Ahok resmi menjadi tersangka.

Kasus Ahok tidak hanya terkait masalah agama Islam dan Kristen saja tetapi juga terkait masalah penduduk pribumi dan non pribumi. Tiba-tiba saja ada perdebatan panas mengenai masyarakat asli dan tidak asli. Ahok pun menjadi contoh yang memadai untuk menunjukkan bahwa etnis Cina merupakan etnis non pribumi atau bisa dikatakan sebagai "bukan masyarakat asli".

Konflik terkait agama dan etnis bukanlah hal baru di negeri ini. Kita tentu tidak mudah melupakan konflik etnis Dayak dan Madura di Sampit; konflik agama di Ambon; dan banyak sekali gesekangesekan antara pendatang dan masyarakat asli yang tidak terekspos media. Orangorang Indonesia terlalu mudah diadu domba hanya karena masalah suku, agama, ras, dan antargolongan (SARA). Kebhinekaan Indonesia jika tidak dijaga dengan baik tentu akan menjadi potensi konflik yang luar biasa.

Beralih dari fenomena konflik yang seringkali mengganggu kestabilan negara Indonesia, Enggano adalah potret nyata bahwa perbedaan mampu hidup damai di Pulau ini. Penduduk Enggano membuktikan bahwa perbedaan agama dan etnis tidaklah menjadi persoalan dalam masyarakat.

Penduduk Enggano pada mulanya mayoritas beragama Kristen tetapi seiring dengan bertambahnya pendatang yang masuk ke Enggano lama kelamaan mayoritas penduduk berganti menjadi Islam. Meskipun begitu, perbedaan agama antara Islam dan Kristen tidak terlalu mencolok karena harmoni di dalam masyarakat Enggano telah meniadakan perbedaan yang mendasar tersebut. Mereka mampu hidup berdampingan tanpa ada konflik di dalamnya.

Agama sebenarnya merupakan hal baru bagi masyarakat Enggano. Agama Kristen masuk pada tahun 1902 yang dibawa oleh misonaris Jerman yang kemudian membuka sekolah zending. Tidak ada pergolakan ketika agama baru masuk ke Enggano. Ini disebabkan karena 
karakteristik orang Enggano yang mudah untuk menerima hal-hal baru yang masuk ke lingkungannya. Begitu pula ketika Islam masuk ke Enggano empat tahun kemudian (1906). Meskipun agama telah masuk pada awal abad ke-19, tidak menghilangkan kepercayaan masyarakat Enggano terhadap roh nenek-moyang mereka. Di setiap kegiatan-kegiatan penting seperti memba ngun rumah, membuka lahan baru, memanen tanaman, membuat jalan, beper gian sendiri maupun rombongan, berburu, dan lain-lain selalu meminta ijin dan restu kepada roh leluhur (Ekorusyono, 2015).

Ekorusyono (2015) juga menjelaskan bahwa ada perbedaan pemujaan yang dilakukan oleh orang-orang Enggano dengan masyarakat Jawa ${ }^{5}$, misalnya. Pemujaan yang dilakukan oleh masyarakat Enggano tidak dilakukan secara khusus seperti di pohon besar, kuil, atau tempat tertentu sebagai sarana pemujaan. Mereka bisa memuja roh leluhur disembarang tempat dan tidak menggunakan sesajen layaknya yang dilakukan masyarakat Jawa dan Bali.

Masyarakat Enggano bisa dikatakan sebagai masyarakat Islam yang abangan ${ }^{6}$. Mereka mengakui bahwa Islam merupakan agamanya tetapi pelaksanaan ritual keislaman masih berbenturan dengan tradisi memuja roh nenek moyang. Seperti yang dikatakan oleh Ekorusyono (2015), orang Enggano menganggap bahwa nenek moyang mereka yang telah mati masih hidup di tanah suci. Dunia yang tidak tampak, tidak bisa dijamah oleh sembarang orang. Roh-roh mereka hidup dalam tatanan alam semesta berbahagia, memiliki kekuatan, bisa diajak berkomunikasi. Orang Enggano menyatakan bahwa roh-roh itu mendiami dunia kosmos tetapi masih di wilayah mereka. Jadi komunikasi bisa dilakukan setiap saat seperti halnya berkomunikasi dengan Tuhan. Bedanya, komunikasi kepada roh leluhur hanya bisa dilakukan oleh elit-elite masyarakat seperti

\footnotetext{
${ }^{5}$ Penekanan dilakukan oleh penulis

${ }^{6}$ Merujuk pada tulisan Geertz tentang Santri, Priyayi, dan Abangan dalam Geertz, Cliford. 1976. The Religion of Java. USA : The University of Chicago.
}

kepala suku, kepala pintu suku atau tokoh adat. $^{7}$

Keyakinan terhadap roh nenek moyang terus menerus dikonstruksi oleh masyarakat Enggano. Mereka terus menerus melakukan ritual-ritual yang diperuntukan kepada roh nenek moyang yang sebenarnya dalam Islam tidak diakui. Pembelaan-pembelaan terhadap adat dan budaya yang lahir terlebih dahulu sebelum datangnya Islam menjadi jalan buntu bagi kita untuk membatasi mereka dari ritual-ritual yang dianggap tidak sejalan dengan ajaran Nabi Muhammad SAW. Pada akhirnya, Islam akan mencari celah agar bisa tetap diterima seperti penyebaran Islam yang dilakukan oleh Walisongo, dengan menjadikan budaya atau kebiasaan masyarakat sebagai sarana penyebaran agama Islam.

Islam, Kristen, dan animismedinamisme mampu berjalan beriringan dalam pulau kecil yang letaknya cukup jauh dari pusat pemerintahan. Hampir tidak ada konflik di pulau ini khususnya terkait dengan perbedaan keyakinan yang selama ini menjadi masalah bagi Indonesia. Begitu juga masalah etnis asli dan pendatang. Masyarakat Enggano mampu meredam perbedaan yang akan menimbulkan konflik di kemudian hari. Mereka memiliki kebijakan untuk menjadikan mendatang menjadi satu suku tersendiri, yang dinamakan Kaamay. Semua pendatang yang masuk ke Enggano, secara otomatis menjadi bagian dari suku Kaamay.

Suku Kaamay terdiri dari campuran suku-bangsa, seperti Jawa, Bugis, Melayu, Batak, Minang, dan lain sebagainya. Identitas asli suku pendatang ini kemudian 'dihilangkan' dan diganti dengan suku Kaamay. Ini adalah proses adaptasi politis yang dimiliki oleh masyarakat Enggano untuk tidak bersaing dengan pendatang tetapi menjadikan mereka 'kawan' untuk sama-sama hidup di bawah aturan adat Enggano.

Meskipun pendatang, suku Kaamay memiliki hak dan kewajiban yang sama dengan kelima suku asli Enggano. Mereka diberikan lahan untuk bertahan hidup, diberikan hak politis untuk mengatur suku mereka dengan memiliki kepala suku

\footnotetext{
${ }^{7}$ Ekorusyono. 2015. Mengenal Budaya Enggano. Yogyakarta : Buku Litera.
} 
sendiri, memiliki hak yang sama untuk menjadi kordinator adat (Pabuki), dan boleh menikah dengan suku asli Enggano. Di sisi lain, mereka wajib untuk tunduk dalam aturan-aturan adat yang selama ini dilakukan oleh nenek moyang orang Enggano. Mereka tidak lagi dianggap pendatang karena mereka sudah memiliki suku dan hak serta kewajibannya sama dengan suku asli Enggano.

Oleh karena itu, hampir tidak ada konflik di Pulau ini. Ini dikarenakan semua yang tinggal di Enggano wajib tunduk pada aturan-aturan adat dan tidak ada keistimewaan ketika seseorang menjadi pendatang atau penduduk asli. Bahkan suku Kaamay boleh berpindah menjadi bagian dari suku asli Enggano dengan upacara dan persetujuan adat, begitu pula sebaliknya.

Mekanisme menyatukan perbedaan menjadi harmoni tentu saja tidak mudah. Selalu ada proses yang dijalani untuk mencapai kedewaan berpikir dan membuat kearifan lokal seperti ini. Jika kita melihat sejarah, dulu Enggano adalah suku yang sangat suka berperang dan mereka hampir kehabisan orang. Orang-orang Enggano sudah melalui perang saudara selama puluhan tahun sampai akhirnya didamaikan oleh Belanda. Belanda mengeluarkan Keputusan Barharu pada tanggal 23 April 1908 sehingga suku di Enggano harus mengadakan suatu perdamaian dan mengikatkan suatu persahabatan dengan suku lainnya yang dikenal sebagai Paano'a. Paano'a inilah yang digunakan untuk mengikat rasa persatuan agar tidak muncul peperangan lagi. Sampai saat ini, suku-suku di Enggano bisa dibilang jauh dari konflik. Belanda menciptakan aturan-aturan yang mengikat mereka sehingga setelah lebih dari 1 abad, tidak ada lagi peperangan di Enggano. Perang yang menghabiskan banyak korban jiwa ini tetap diingat dalam bentuk tarian perang. Tarian ini digunakan untuk mengingat kejadian perang yang pernah terjadi. Di sisi lain, orang Enggano memiliki tarian yang dinamakan tarian semut. Tarian ini melambangkan rasa satu keturunan dari nenek moyang yang sama (Ekorusyono, 2015 : 180).

Indonesia sebaiknya belajar dari Enggano, bagaimana mereka mampu mengesampingkan perbedaan agama dan suku bangsa, yang di tempat lain bisa saja menjadi polemik baru, dan mampu mengedepankan Bhineka Tunggal lka. Padahal, Pulau Enggano terletak cukup jauh dari akses pemerintahan (Provinsi Bengkulu). Butuh waktu 12 jam perjalanan laut untuk bisa sampai ke sana. Akan tetapi, dari pulau kecil inilah kita belajar tentang pentingnya menjaga harmoni dalam perbedaan.

Masyarakat Enggano sangat menghargai konsep harmoni. Mereka mengubur berbagai perbedaan yang ada dalam masyarakat dan menjadikannya satu di bawah adat dan budaya Enggano.

\section{F. KESIMPULAN}

$\mathrm{M}$ emahami cara berpikir orang Enggano sungguh menarik. Cara berpikir orang Enggano sangat moderen, mengerti potensi konflik, mema hami cara mencegahnya, dan bisa menjadi contoh konsep kebhinekaan yang selama ini digalang-galangkan oleh pemerintah Indonesia.

Orang-orang Enggano dari awal menyadari bahwa potensi konflik cepat atau lambat akan mengganggu kenyaman hidup mereka. Mereka sadar bahwa kehadiran pendatang tidak bisa dihalang-halangi dan suka tidak suka akan menduduki pulau mereka. Untuk mengantisipasi kondisi tersebut, mereka mengambil langkah politis yang luar biasa yaitu menjadikan pendatang bagian dari kehidupan bermasyarakat mereka. Mereka membuat kebijakan politis untuk memberikan mereka suku tersendiri dan hak-haknya diakui sama seperti suku asli. Hal ini sebenarnya dilakukan untuk mencegah pendatang merusak sistem sosial budaya serta adat mereka dengan membawa nilai-nilai baru.

Keragamaan keyakinan dan agama di Enggano tidak membuat mereka saling memusuhi satu sama lain. Mereka saling mendukung dan membantu tidak peduli latar belakang keagamaan mereka. Agama bagi mereka bukanlah hal yang menjadi pemisah karena pada dasarnya sesama mereka adalah keluarga, yang disatukan dalam adat dan kebudayaan yang mereka junjung tinggi, yaitu kebudayaan Enggano. 


\section{DAFTAR PUSTAKA}

Abdullah, Irwan. 2001. "Penggunaan dan Penyalahgunaan Kebudayaan di Indonesia: Kebijakan Negara dalam Pemecahan Konflik Etnis" Antropologi Indonesia, No. 66

Effendi Nursyirwan. 1993. "Masyarakat Enggano di Sebelah Barat Sumatra" dalam Koetjaraningrat (Ed.) Masyarakat Terasing di Indonesia. Jakarta : PT. Gramedia (hal 74-99).

Ekorusyono. 2015. Mengenal Budaya Enggano. Yogyakarta : Buku Litera.

Firmansyah. 2016. "Belajar Keberagaman dari Suku Petempur di Pulau Enggano". http://regional.kompas.com/read/2016/08/18/22220051/Belajar.Keberagaman.dari.Suk u.Petempur.di.Pulau.Enggano. 19 Mei 2017.

Geertz, Cliford. 1976. The Religion of Java. USA : The University of Chicago.

Keurs, Pieter Ter. 2002. "Eakalea: A Ritual Feast On Enggano Island, Viewed From A Regional Perspective". Indonesia and the Malay World, Vol. 30, No. 88.

M. A. Jaspan. (1964). 133. "A Note on Enggano". Man, 64, 109-113. doi: 10.2307/2797362

Pelly, Usman. 1999. "Akar Kerusuhan Etnis di Indonesia : Suatu Kajian Awal Konflik dan Disintegrasi Nasional di Era Reformasi" Antropologi Indonesia, No. 58.

Sari, Intan Permata. 2015. "Konstruksi Media atas Realitas Politik: Tafsir Pemberitaan Pemilihan Presiden 2014". Tesis. Yogyakarta: Universitas Gadjah Mada. 